\title{
The Perception of Fair Remuneration as a Component of Sustainable Development
}

\author{
HANNA KinOWSKA \\ Institute of Human Capital, Collegium of Business Administration, \\ SGH Warsaw School of Economics
}

\begin{abstract}
Sustainable development leads to the satisfaction of basic human needs, while maintaining the integrity of the ecosystem. The implementation of sustainable development principles in an organisation requires its transformation. The diversity of changes requires support from human capital management. It is essential to reach the foundations of the functioning of an organisation, encompassing the basic principles of its operation. The engagement of employees, which is necessary to follow the principles of sustainable development, implies the need to use a comprehensive set of instruments under the broadly conceived remuneration system. The basic criterion for its assessment is fairness.
\end{abstract}

Keywords: sustainable development, remuneration, organisational justice, fair remuneration JEL Classification Codes: M52, M54 


\section{Introduction}

Despite abundant literature devoted to the ecological and economic aspects of sustainable development, it remains poorly explored in organisational terms. The conscious implementation of an environmental management system geared to sustainable development is a multi-directional process that changes the perspective of an enterprise's operations. It provides a starting point for the creation of a sustainable development organisation. The transformation of an enterprise designed to enable it to pursue new objectives cannot be indifferent to the enterprise itself.

Sustainable development makes it necessary to concentrate simultaneously on innovation management, cultural diversity, and environmental issues. It requires the engagement of employees, which is based on a set of practices enabling the individualisation of motivational solutions affecting the behaviours of particular employees. It is founded on the perception of the organisation as a whole, and in particular the remuneration system, as fair.

The purpose of this article is to explore the role of perception of fair remuneration in the context of sustainable development. The basis is the broadly conceived sustainable development, defined based on the course of its evolution. Interactions between sustainable development and human capital management and between organisational justice in general and fairness of remuneration in particular were determined based on a review of the relevant literature.

\section{Sustainable development}

Sustainable development is an economic concept that advocates maintaining life quality and environment management at a level enabling civilisational development, while preserving or even restoring exploited natural resources.

Originally, the concept of sustainable development was associated with ideas promoted already in the $19^{\text {th }}$ century by the German Higher Schools of Forestry. It derives from the works of a seventeenth-century German property administrator, Hans Carl von Carlowitz. In the contemporary sense, it referred to forest management ensuring that logging did not ravage forest resources and enabled continuous development and regeneration. The term 'sustainable development' functioned in this shape - as a slogan of environmental movements - until the 1980s. A broader sense of the concept of sustainable development was popularised and adopted by the wider public opinion thanks to the report Our Common Future, drawn up in 1987 under the direction of Gro Harlem Brundtland, Chairperson of the World Commission 
on Environment and Development (WCED) (Brundtland, 1987).The Brundtland Commission defined sustainable development as meeting the needs of the present without compromising the ability of future generations to meet their own needs. The definition is based on two key concepts: that of 'needs', in particular, the essential needs of the world's poor, to which overriding priority should be given, and that of 'limitations', imposed by the state of technology and social organisation on the environment's ability to meet present and future needs (Brundtland, 1987). The core of the definition is made up of the concept of basic needs, the idea of limited abilities, and the capacities of the global ecological system (Stappen, 2006).

An even broader sense is given to 'sustainable development' by standards and documents of the United Nations. They define it as development that meets the basic needs of all human beings and which conserves, protects and restores the health and integrity of the Earth's ecosystem, without compromising the ability of future generations to meet their own needs and without going over the limits of long-term capacity of the Earth's ecosystem (Stappen, 2006).

Despite the existence of an established definition of sustainable development and the implementation of its principles as paradigms for enterprises, governments or NGOs to incorporate in their development, its implementation lacks coherence. The literature contains opinions indicating an incomplete perception of the problems of poverty and environmental degradation, as well as difficulties in placing the concept of sustainable development in the context of the still lively paradigm of continuous economic growth (Lélé, 1991).

From organisations' perspective, sustainable development is connected with the concept of environmental (pro-ecological) management, which includes intentional actions aimed at maintaining and improving the state of the natural environment affected by the company's activities (Nierzwicki, 2006). In practice, the implementation of an environmental management strategy is aimed at gaining a competitive advantage. As the awareness of climate change is increasing, enterprises cannot dissociate themselves from the issue of environmental protection. There is a growing demand for products and services that emphasise their individual responsibility for the state of the ecosystem.

\section{The sustainable development of an organisation and human capital}

The ambiguity of the concepts included in the definition of sustainable development leaves considerable room for interpretation. The combination of concerns related to the basic existence and the state of climate with social and economic issues may 
give rise to many conflicts. The process of changes that must be introduced to prevent the irreversible degradation of the environment is incompatible with aspirations for continuous development and improving the quality of life. Scientists point out the need to favour sustainable livelihoods and an appropriate quality of life (well-being) over consumption (well-having). This leads to calls for social and environmental activities aimed at balancing human capital (Hopwood, Mellor, \& O’Brien, 2005).

The sustainable development of organisations is perceived as the key issue by practitioners. A study conducted by researchers of the MIT Sloan Institute (Kiron, Kruschwitz, Haanaes, \& Velken, 2012) over three consecutive years, from 2009 to 2011, on a sample of over 2000 managers and officers from over 100 countries, indicates a considerable increase (from 25\% in 2009 to $68 \%$ in 2011) in the involvement of managers in the sustainable development of organisations. In 2011, 67\% of the respondents perceived sustainable development as crucial to competitive advantage.

Sustainable development is a complex construct. In practice, it requires making investments while maintaining continuity in adding to the organisation's value, by increasing the value for shareholders and protecting the environment at the same time. This implies concentration on a broad range of stakeholders, going beyond the selected group of owners, often only financial, represented by hedge or pension funds. It is not enough to measure the results of the organisation with economic indicators. This needs to be complemented with the concern for the natural environment and the need to preserve it for future generations.

Acting in accordance with the principles of sustainable development brings appropriate results if it takes into consideration the environmental, economic, and social areas at the same time. The first area relates to the organisation's real impact on the environment. The economic aspect is related to financial results and the provision of products or services that meet consumers' requirements in the area of responsibility for the environment. Here, the economic dimension interacts with the environmental dimension, involving the organisation's effort to operate in accordance with the principles of sustainable development and to protect natural resources. The social dimension overlaps with the other two, e.g. employees as consumers evaluate whether the products or services delivered by their company meet their expected standards of environmental impact.

The social dimension encompasses issues of building an organisation that enhances the engagement of employees in issues that are important to them and makes it possible e.g. to maintain a balance between the working time and the time for oneself and one's family (work-life balance). The social exchange theory suggests that employee engagement is of key importance to improving the results of activities aimed at organisational sustainability. An important element enhancing involvement is the organisational justice of an enterprise. It leads to a greater degree of knowledge 
sharing between employees and to an increased frequency of innovative behaviours (Woocheol \& Jiwon, 2017).

The introduction of an environmental management system requires ideas that bring an organisation together. It is a costly and time-consuming process. The relationship between human resources and organisational sustainability, which is based on economic, social and environmental performance, involves some important aspects concerning management, such as innovation, cultural diversity and the environment (Jabbour \& Santos, 2008). The concept of sustainable development must be implemented in a precise and well-thought-out manner at the stages of planning, implementation, measurement, and assessment (Daily \& Huang, 2001). The transformation of an organisation should cover all organisational levels. This requires coordinating human resources management activities, in particular: special training, support for employees and new teams, and an appropriate remuneration system.

The transformation of the organisational culture towards sustainable development is a multi-directional process. It cannot be carried out chaotically or only as a bottom-up initiative. An enterprise may and should exploit the innovative enthusiasm of involved employees, but the framework for the new construction and the lines of action should be incorporated in the principles of human resources management.

A body responsible for HRM as the centre of the sustainable development transformation of an organisation is selected based on its functioning. It enables to integrate the principles of sustainable development into the operation of an organisation (Vickers, 2005). Human resources management, in accordance with the modern concepts and the principles of sustainable development, requires the longtime targeting of activities going beyond the narrow bounds of the need to strive for specific economic results (Wilkinson, Hill, \& Gollan, 2001). Modern human resources management must meet the needs of many stakeholders (Colakoglu, Lepak, \& Hong, 2006; Juchnowicz, 2016), and the sustainable development of an organisation is becoming a paradigm of human resources management (Boudreau \& Ramstad, 2005).

Sustainable development makes it necessary to recalibrate the objectives of human resources management. From the point of view of a traditional enterprise, activities would be considered in terms of improving the financial results or the required return on investment. A modern organisation must look beyond the profit and loss account, paying attention especially to sustaining the enterprise's operations in the future, and thus should act in accordance with the principles of sustainable development (Jabbour \& Santos, 2008). This makes it necessary for the HRM strategy to concentrate on innovation management, cultural diversity, and environmental issues. It requires a set of practices that will support the objectives mentioned above and experts and leaders responsible for transformation towards sustainable development and its integration into the everyday functioning of the organisation. 
The implementation of such practices results in enhanced innovativeness of the organisation, which offers greater possibilities for investing in human capital, which, in turn, improves the company's results in the economic, social, and environmental areas. Sustainable organisations are rated more highly by customers and shareholders. They gain a better reputation, which allows them to reach for new resources, making it possible to finance ambitious investment projects and thus continue to develop in innovative, social, and environmental areas.

\section{Fairness of remuneration}

The functioning of an enterprise under sustainable development conditions requires the engagement of employees. It is founded on a sense of justice in the enterprise. It is an element enhancing employees' willingness to share knowledge and innovative work behaviour (Karkoulian, Assaker, \& Hallak, 2016).

Employee engagement requires a specific approach to motivating. It involves the ability to inspire. Traditional motivation methods consist in consciously influencing employees so that they achieve the objectives of the motivating person. It leads to behaviours triggered by a stimulus. Inspiring requires a partnership between the organisation and its employees. It leads to the unleashing of the creative potential of employees. It requires an organisation to create appropriate conditions for customising solutions shaping employee behaviours under a comprehensive motivational system that is identified with the remuneration system (Juchnowicz, 2012).

Remuneration is one of the factors that influence the attitudes of employees most strongly. Modern management gives it a broad sense. It encompasses all financial and non-financial benefits that an employee receives in exchange for their work. They form a package supporting the achievement of the company's objectives and, at the same time, taking into account the needs and values of employees. Fairness is the key parameter in the assessment of remuneration by employees. Through fair remuneration, the company encourages its employees to develop and enhance their performance.

In management and quality sciences, fairness of remuneration is placed in the context of organisational justice. It means a sense of justice relating to the functioning of the organisation in many areas, including: the division of remunerations, the possibilities of development and promotion, bonus-granting criteria, promotion rules, feedback rules, etc. Organisational justice is made up of three elements: procedural justice, distributive justice, and interactional justice, which together have a positive effect on employees' comfort and reduce the level of stress at work, which contributes to a fairer working environment. 
Research results confirm that organisational sustainability requires work engagement supported by perceived procedural justice, which leads to knowledge sharing and increased internal innovativeness (Woocheol \& Jiwon, 2017). Research also shows that procedural justice and interactional justice have a positive influence on organisational sustainability, being its strong predictors (Karkoulian, Assaker, \& Hallak, 2016).

Historically, the first component of organisational justice is distributive justice. It is usually directly associated with the assessment of remuneration. According to Adams' equity theory (1963), employees compare their effort with others. Based on the result of that comparison, they formulate an assessment of fairness. If an employee expends more effort than the reference person but does not receive a proportionally higher reward, they perceive this lack of balance as unfair.

In practice, organisational justice turned out to be a construct more complex than a simple comparison of the input-output distribution. It became necessary to take into account the justice of procedures (Thibaut \& Walker, 1975). The probability that a decision will be accepted increases if the parties involved consider the process leading to that decision as fair and impartial. Rules for the functioning of just organisational procedures were developed, including: equal application of a given procedure, lack of bias, precision of information affecting the outcome of the procedure, taking into account the possibility of correcting erroneous or inaccurate decisions, consistent application of ethical and moral standards, and inclusion of the persons concerned in the process (Leventhal, 1980).

An appropriate distribution of benefits and adequate procedures did not guarantee that an organisation would be assessed as just. This may stem from inappropriate behaviours of managers and poor relations with employees. Researchers recognised the need for interpersonal relations to be taken into account in the perception of justice (Bies, 2001). This dimension was labelled as interactional justice. Researchers proposed its division into interpersonal and informational justice (Greenberg, 1993). The former refers to human relations. The latter focuses on the amount, precision, and quality of information provided to employees. Interpersonal justice refers to interpersonal communication and informational justice concerns any communications, also messages transmitted via impersonal or formal channels.

The exploration of the perception of fairness of remuneration by Polish employees suggests that they make their assessments based on complex factors. There is no justification for reducing fairness of remuneration to a simple input-output comparison (distributive justice). Irrespective of the remuneration level, the perception of remuneration as fair is affected most strongly by the perception of the superior's behaviours as proper, and in particular the belief that the superior takes care of adequate remuneration. This means that a key role is played by the 
interactional dimension, which traditionally is not associated with remuneration assessment in the literature (Kinowska, 2018). The specific features of the fairness assessment by Polish employees make it necessary to take the local conditions into consideration when establishing the remuneration rules. This also implies that it is impossible to apply universal rules for assessing fairness in the workplace.

\section{Conclusion}

Summarising the results of research described in the literature, one can conclude that sustainable development and fairness of remuneration are multidimensional constructs that have not been sufficiently explored yet. There is a need for empirical research on relations between these constructs. The existence of relations between fairness of remuneration and sustainable development is explained based on the social exchange theory, taking into account the role of engagement. Due to the situational conditioning of engagement and fairness assessment, it seems necessary to explore these issues in specific contexts. The relationship between sustainable development and fairness of remuneration is both important and insufficiently explored. It requires in-depth research conducted on samples having predefined characteristics.

\section{References}

Adams, S. (1965). Inequity in social Exchange. In: L. Berkowitz (Ed.), Advances in Experimental Social Psychology. New York: Academic Press.

Bies, R.J. (2001). Interactional in (justice): the sacred and the profane. In: J. Greenberg, R. Cropanzano (Eds.), Advances in Organizational Justice. Stanford: Stanford University.

Boudreau, J.W., \& Ramstad, P.M. (2005). Talentship, Talent Segmentation and Sustainability: A New HR Decision Science Paradigm for a New Strategy Definition. Human Resource Management, 44(2), 129-136.

Brundtland, G.H. (1987). Report of the World Commission on Environment and Development: Our Common Future. Retrieved from: https://sustainabledevelopment.un.org/content/ documents/5987our-common-future.pdf (29.10.2019).

Colakoglu, S., Lepak, D.P., \& Hong, Y. (2006). Measuring, HRM Effectiveness: Considering Multiples Stakeholders in a Global Context. Human Resource Management Review, 16, 209-218.

Daily, B.F., \& Huang, S. (2001). Achieving sustainability through attention to human resource factors in environmental management. International Journal of Operations \& Production Management, 21(12), 1539-1552. 
Greenberg, J. (1993). The social sideoffairness: interpersonal and informational classes of organizational justice. In: R. Cropanzano (Ed.), Justice in the Workplace: Approaching Fairness in Human Resource Management. Hillsdale: Erlbaum.

Hopwood, B., Mellor, M., \& O’Brien, G. (2005), Sustainable development: mapping different approaches. Sustainable Development, 13(1), 38-52.

Jabbour, Ch.J.Ch., \& Santos, F.C.A. (2008). The central role of human resource management in the search for sustainable organizations. The International Journal of Human Resource Management, 19(12), 2133-2154.

Juchnowicz, M. (2012). Zaangażowanie pracowników. Sposoby oceny i motywowania. Warszawa: PWE.

Juchnowicz, M. (2016). Elastyczne zarzq̨dzanie kapitałem ludzkim. Warszawa: PWE.

Karkoulian, S., Assaker, G., \& Hallak, R. (2016). An empirical study of 360-degree feedback, organizational justice and firm sustainability. Journal of Business Research, 69(5), 1862-1867.

Kinowska, H. (2018). Zróżnicowanie oceny sprawiedliwości wynagradzania w zależności od poziomu płac. Edukacja Ekonomistów i Menedżerów. Problemy. Innowacje. Projekty, 49(3), 83-98.

Kiron, D., Kruschwitz, N., Haanaes, K., \&Velken, I.V.S. (2012). Sustainability nears a tipping point. MIT Sloan Management Review, 53(69), 69-74.

Lélé, S.M. (1991). Sustainable development: A critical review. World Development, 19(6), 607-621.

Leventhal, G.S. (1980). What should be done with equity theory? New approaches to the study of fairness in social relationships. In: K. Gergen, M. Greenberg, R. Willis (Eds.), Social Exchange: Advances in Theory and Research. New York: Springer-Verlag. Nierzwicki, W. (2006). Zarządzanie środowiskowe. Warszawa: PWE.

Stappen, R.K. (2006). Sustainable development, New York.

Thibaut, J., \&Walker, L. (1975). Procedural Justice: A Psychological Analysis. Hillsdale: Erlbaum.

Vickers, M.R. (2005), Business Ethics and the HR Role: Past, Present, and Future. Human Resource Planning, 28(1), 26-32.

Wilkinson, A., Hill, M., \& Gollan, P. (2001). The Sustainability Debate. International Journal of Operations \& Production Management, 21(12), 1492-1502.

Woocheol, K., \& Jiwon, P. (2017). Examining Structural Relationships between Work Engagement, Organizational Procedural Justice, Knowledge Sharing, and Innovative Work Behavior for Sustainable Organizations. Sustainability, 9(2), 205. 


\section{Hanna Kinowska}

Holds a PhD in economics, Assistant Professor at the Institute of Human Capital at SGH Warsaw School of Economics, lecturer, author of many publications on human capital management. Associated with practice, she has carried out numerous projects improving human capital management, especially in the areas of remuneration systems and employee engagement.

e-mail address: hkinows@sgh.waw.pl

ORCID: 0000-0002-7936-9737 


\section{Printing and binding \\ QUICK-DRUK s.c. tel. 426395292 \\ e-mail: quick@druk.pdi.pl}

Order $64 / \mathrm{VI} / 20$

\section{INFORMATION FOR THE AUTHORS}

\section{General information}

1. The editors of the quarterly accept scientific articles and research reports (up to 15 pages of standardised computer printer/typewritten/text including bibliography) as well as book reviews, information of conferences, symposiums, scientific seminars (up to 6 pages long).

2. Papers shall concern issues within the field of management and widely understood professional development. They should meet requirements of top scientific standards: high subject-of-the matter level, relevant and up-to-date problem area, application possibility, originality and contribution in the hitherto accomplishments in the specific field, language accuracy.

3. The article should follow the following layout: title, name and surname, and the author's affiliation, abstract (summary) of the article (up to 900 characters with spaces) key words (5-7), the full text of the article, bibliography, information about the author (up to 900 characters with spaces).

4. The article should identify the following parts and elements: introduction with a clearly stated objective, the main part including the theoretical or empirical problem presentation, final conclusions.

5. The standard of text preparation:

- Times New Roman 12, space between lines 1.5, margins $2.5 \mathrm{~cm}$,

- bibliography footnotes at the bottom of the page arranged as follows,

- bibliographic references within the text (the Harvard style) in the following order: name of the author, year of publication,

- drawings and tables within the text, entitled, provided with sources,

- bibliography at the end of the article, in the alphabetical order: name of the author, first letter of the author's first name, year of publication, title of the book/article, place of publication, publisher.

\section{Example:}

Armstrong, A. (2005). Zarządzanie zasobami ludzkimi. Kraków: Oficyna Ekonomiczna. Organ, D.W., Podsakoff, P.M., \& MacKenzie S.B. (2006). Organizational Citizenship Behavior: Its Nature, Antecedents, and Consequences. Thousand Oaks, CA: Sage.

Juchnowicz, M. (2014). Istota i struktura kapitału ludzkiego. In: M. Juchnowicz (Ed.), Zarządzanie kapitatem ludzkim. Procesy, narzędzia, aplikacje, Warszawa: PWE, 29-37. Anderson, N. \& Gasteiger, R.M. (2008). Helping Creativity and Innovation Thrive in Organizations: Functional and Dysfunctional Perspectives. In: J. Langan-Fox, 
C.L. Cooper, R.J. Klimoski (Eds.), Research companion to the dysfunctional workplace Cheltenham, UK: Edward Elgar Publishing, Inc., 422-440.

Zhang, Y., Lepine, J., Buckman, B. R., Wei, F. (2014). It's Not Fair... or Is It? The Role of Justice and Leadership in Explaining Work Stressor-job Performance Relationship. Academy of Management Journal, 57(3), 675-697.

6. The text can be e-mailed to the editorial office: ikl@sgh.waw.pl. The article paper version shall be posted to the address of the editorial office.

7. Meeting the requirements concerning the right preparation of the text andreceiving a positive opinion of reviewers is a prerequisite to acceptance of the text.

8. In order to prevent the phenomena of 'ghostwriting', 'guest authorship' and to ensure scientific diligence, the author shall be obliged to reveal their own and co-authors' contribution in the publication (providing their affiliation and involvement, i.e. information on who are the authors of the concept, assumptions, methods, etc. used while preparing the publication) with the major responsibility being borne by the author submitting the article for publication. Any detected cases of a lack of due diligence and dishonesty will be revealed, followed by informing appropriate entities.

9. The journal adheres to the Core Practices of the Committee on Publication Ethics (COPE, https://publicationethics.org/core-practices) and follows their guidelines in respect of publication ethics and managing problems when they arise.

\section{The quarterly's reviewing procedure and rules}

1. Positive reviews of two independent reviewers are the prerequisite to the publication of the article.

2. Reviewers are appointed from among those being outside the scientific unit publishing the quarterly.

3. Double-blind review process is obligatory.

4. A review is made in writing, by filling in a suitable form including the substantive and formal assessment criteria. A reviewer presents the justification of the article assessment as well as suggestions of changes of both the subject-of-the-matter and editorial nature.

5. A reviewer presents the final recommendation - a decision concerning the rejection on the article, the necessity for the article to be reviewed again (following necessary changes to the article or accepting the article to be printed).

\section{List of regular reviewers}

Prof. Piotr Błędowski, PhD (SGH Warsaw School of Economics, Warsaw, Poland)

Prof. Christina Ciecierski, PhD (Northeastern Illinois University, Chicago, USA)

Prof. Zdzisława Janowska, PhD (University of Business and Administration in Gdynia, University of Lodz, Polska)

Prof. Hanna Karaszewska, PhD (UTP University of Science and Technology in Bydgoszcz, Bydgoszcz, Poland)

Prof. Alicja Miś, PhD (Cracow University of Economics, Cracow, Poland)

Prof. Renata Oczkowska, PhD (Cracow University of Economics, Cracow, Poland)

Prof. Tadeusz Oleksyn, PhD (University of Finance and Management, Warsaw, Poland)

Prof. Józef Orczyk, PhD (Poznań University of Economics and Business, Poznan, Poland)

Prof. Roman Sobiecki, PhD (SGH Warsaw School of Economics, Warsaw, Poland) 